\title{
History and perspective of herbicide use in Australia and New Zealand
}

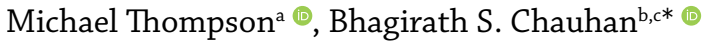 \\ aQueensland Alliance for Agriculture and Food Innovation (QAAFI), The University of Queensland, Gatton, 4343, QLD, Australia, b Queensland \\ Alliance for Agriculture and Food Innovation (QAAFI)/School of Agriculture and Food Sciences (SAFS), The University of Queensland, Gatton, 4343, \\ QLD, Australia; ' Chaudhary Charan Singh Haryana Agricultural University (CCSHAU), Hisar, Haryana 125004, India.
}

\begin{abstract}
Farming began in Australia and New Zealand after the arrival of European settlers, who brought with them many of the weeds that later infested their cropping systems. Herbicides have since become the dominant form of weed control in both countries. Early active ingredients, such as 2,4D, were unable to control all types of weeds, sparking the development of many other herbicides with different modes of action. While most of the land in these countries is used for pasture, many crops are also grown, with an emphasis on grains, including wheat, barley, and oats, as well as horticultural crops in New Zealand such as wine grapes, kiwifruit, and apples. An overreliance on herbicide use due to their high level of effectiveness for weed control has led to the evolution of herbicide-resistant weeds, with some
\end{abstract}

weed populations developing resistance to multiple herbicide modes of action. Integrated weed management practices have been adopted by many farmers to reduce the reliance on herbicides, although widespread uptake is yet to occur. These practices use non-chemical methods in combination with herbicides to deal with hard-to-control and herbicide-resistant populations, as well as reduce the risk of resistance development. In addition to resistance, other concerns surrounding herbicide use also exist, such as the impact of herbicides on human health and the environment. This review summarizes the history of herbicides in Australia and New Zealand and discusses the issues surrounding their use as well as potential future directions for sustainable weed control.

Keywords: Glyphosate; herbicide ban; chemical control; herbicide drift; resistance

Journal Information:

ISSN - 2675-9462

Website: http://awsjournal.org

Journal of the Brazilian Weed

Science Society

How to cite: Thompson M, Chauhan BS. History and perspective of herbicide use in Australia and New Zealand. Adv Weed Sci. 2022;40(Spec1):e20210075. hitps///doiorg/10.51694/AdWWeedSa/2022;40:seventy-five002

Approved by:

Editor in Chief: Carlos Eduardo Schaedler

Associate Editor: Luis Antonio de Avila

Conflict of Interest: The authors declare that there is no conflict of interest regarding the publication of this manuscript

Received: August 1st, 2021

Approved: October 27, 2021

* Corresponding author: <b.chauhan@uq.edu.au>

\section{(c) (1)}

This is an open-access article distributed under the terms of the

Creative Commons Attribution License, which permits unrestricted use, distribution, and reproduction in any medium, provided that the original author and source are credited.

Copyright: 2021

\section{Introduction}

Modern agriculture relies heavily on chemicals to control weeds in agricultural systems, which are a major issue in systems around the world, causing large economic losses through decreasing crop yields (Llewellyn et al., 2016). As such, control of agricultural weeds is a major concern for growers. Since the development of the first synthetic active ingredient in the 1940s, herbicides have become the dominant form of weed control. This shift in weed control technology reduced the need for manually removing weeds and required growers to learn new equipment and farming practices. Currently, many different groups of herbicides are available, with each killing weeds via a distinct mode of action (MOA).

Long-term overreliance on herbicides for weed control by growers around the world resulted in selection of weeds with resistance to herbicides in many countries, including Australia and New Zealand (Heap, 1997). Australia has become one of the leading countries in the number of cases of herbicide-resistant weeds (Heap, 1997; 2021). By repeatedly applying herbicides with the same MOA, plants possessing alleles that confer resistance to the herbicide have a greater chance of surviving and producing seeds, thus increasing the frequency of the resistant alleles in the population and leading to the evolution of herbicide resistance. Resistance may be due to mechanisms categorized as two types: target-site and non-target-site resistance. Target-site resistance can occur as a mutation in the target gene or overexpression of the target gene, while non-target-site resistance relates to resistance mechanisms involving herbicide uptake, translocation, metabolism, sequestration and rate of herbicide activation (Jugulam, Shyam, 2019).

Glyphosate has become the most dominant herbicide, in part due to the development of glyphosate-resistant crops, which allowed growers to apply glyphosate to weeds without concern over it killing the crop. However, the large-scale application of glyphosate resulted in glyphosate-resistant weed populations, despite some considering the risk to be low (Green, 2018). In addition, multiple herbicide resistance in weed populations has increased in Australia, particularly in Lolium rigidum (Owen et al., 2014), further reducing the available chemical control options.

The rise in resistant weeds, including those with glyphosate resistance, has increased the need for more diverse weed management practices in addition to practices, 
which help to reduce the risk of resistance evolution or deal with current resistant populations. Integrated weed management (IWM) strategies, which combine multiple control methods, are important for diversifying control practices and, therefore, minimizing the need for herbicides; however, uptake of IWM by growers has been slow (Swanton et al., 2008). Further research on weed biology and IWM is crucial for identifying effective control strategies for specific weeds and environments. Australia has been among the top countries in the world in terms of the number of publications for weed control methodology (Harker, O’Donovan, 2013).

The purpose of this review is to highlight the history of herbicide use in Australia and New Zealand and the challenges these countries face surrounding the use of herbicides, including herbicide resistance and the loss of herbicides as a dominant form of weed control. In addition, we discuss the prospects for weed control.

\section{History of herbicide use in Australia and New Zealand}

Farming began in Australia shortly after the arrival of the First Fleet in 1788, when colonists began to grow crops such as wheat and barley (State Library of New South Wales, 2021, Figure 1). When European settlements spread to New Zealand in 1840, the Maori began adopting European farming techniques and were soon exporting grain and potatoes to Australia in the 1850s and 60s (Peden, 2008). With the rise in agriculture came the problem of weeds, most of which were not native plant species but had been introduced. Some weeds came into the country hidden in imported goods, while others were deliberately introduced to serve a specific purpose. For example, L. rigidum, one of the most significant weeds in Australia, was first planted as pasture to feed sheep (Stokstad, 2013). With weeds threatening agricultural productivity, control methods had to be implemented to deal with the problem.

Early methods of weed management focused on removing weeds by hand or hoe, burning the stubble, cultivation, harrowing, and setting sheep to fallow fields (Department of Primary Industries and Regions South Australia, 2017). With shortages in labor available to manually remove weeds, farmers required other methods of weed control, which came in the form of herbicides. Herbicides first appeared as a method of weed control in the form of inorganic salts and acids (Norman et al., 1950). In New Zealand, chemicals such as arsenic, sodium chloride, sodium chlorate, and sulfuric acid were used as herbicides in the 1930s, alongside the first organic herbicide, (Popay, 2008). However, most of these herbicides were toxic. With increasing infestations of Senecio vulgaris in New Zealand in the 1930s, farmers began to rely on sodium chlorate; however, many reports arose of clothing catching fire due to contact with this chemical (Watson, 2004).

A revolution in herbicide development occurred during the time of World War II. In the 1940s, four groups of researchers spread across the United States and the United Kingdom each made discoveries of several chlorophenoxyacetic acids that could serve as selective herbicides (Troyer, 2001). The discoveries made by each group were made independently of one another, unaware that other researchers had made the same discovery due to the lack of publications and the control that each country's government maintained over science in light of the war. These herbicides were 2,4-D, 2,4,5-T, and MCPA, and due to their effectiveness, they became not only a serious focus in agriculture but also in warfare as they showed potential to destroy the enemy's crops and vegetation. In 1942, the War Research Service was established as a civilian agency of the United States government, which took control of biological warfare research, including the use of these herbicides being researched at the time (Peterson, 1967). Of the three chlorophenoxyacetic acids mentioned, 2,4-D went on to become the most widely used herbicide. In Australia, the use of 2,4-D and MCPA began in 1948, where it was used in wheat crops to control Brassica tournefortii, Raphanus raphanistrum, Sisymbrium officinale, and Carthamus lanatus (Department of Primary Industries and Regions South Australia, 2017). These herbicides were also taken up by New Zealand farmers. Use of 2,4,5-T occurred in New Zealand into the late 1980s for application to gorse and scrub, but this ended due to public health concerns (Popay, 2008). Both 2,4-D and MCPA are still currently in use for the control of broadleaf weeds in Australia and New Zealand.

While 2,4-D and MCPA were effective for controlling broadleaf weeds, they were unable to control the many grass species that infested cropping fields. Since the discovery of 2,4-D in the 1940s, many herbicides with new modes of action were discovered and incorporated into weed management programs across Australia and New Zealand which allowed farmers to control a further variety of weed species. In South Australia, over 80 commercial herbicides were available by the early 1970s (Department of Primary Industries and Regions South Australia, 2017). This included atrazine, a selective systemic triazine herbicide that was developed in the 1950s and has since been put to wide use as a pre- and post-emergent herbicide capable of controlling grass and broadleaf weed crops in various summer crops, such as sorghum, maize, and sugarcane (Australian Pesticides \& Veterinary Medicines Authority, 2008). Despite concerns over water contamination from this herbicide, it has been deemed safe and is still used in Australia and New Zealand.

While discovered in 1955 and first available in the US in 1962, paraquat is a non-selective contact herbicide first registered in Australia in 1964 (Australian Pesticides \& Veterinary Medicines Authority, 2016). Paraquat is a broad-spectrum herbicide capable of controlling grasses and broadleaf weeds and has had various restrictions placed on its use since it became available (Environmental Protection Authority, 2019). Out of the many herbicides 
developed since the herbicide revolution in the 1940s, glyphosate has become the most dominant herbicide in the world, including in Australia and New Zealand.

Glyphosate came onto the market in Australia and New Zealand in the 1970s after it was first released in the United States in 1974 as a post-emergence, non-selective herbicide (Duke, Powles, 2008; Environmental Protection Authority, 2021). Since its introduction, there have been around 500 products that have been registered in Australia that contain glyphosate (Australian Pesticides \& Veterinary Medicines Authority, 2019). Glyphosate's effectiveness is owed to its systemic activity and ability to inhibit the enzyme 5-enolpyruvyl-shikimate-3-phosphate synthase in all higher plants, making it effective for a large range of species (Duke, Powles, 2008). In Australia, this herbicide has been predominately used prior to crop sowing in grain cropping systems (Neve et al., 2003). In New Zealand, glyphosate also became important for its application in pasture renewal (Manktelow et al., 2005). Manktelow et al. (2005) reported an increase in sales of glyphosate in New Zealand of 35\% between 1999 and 2003, probably due to the reduction of the price. Glyphosate-resistant (GR) crops have also caused a large increase in reliance on glyphosate to control weeds. GR cotton was introduced in Australia in 2000 and has since gone on to occupy $99.9 \%$ of all cotton

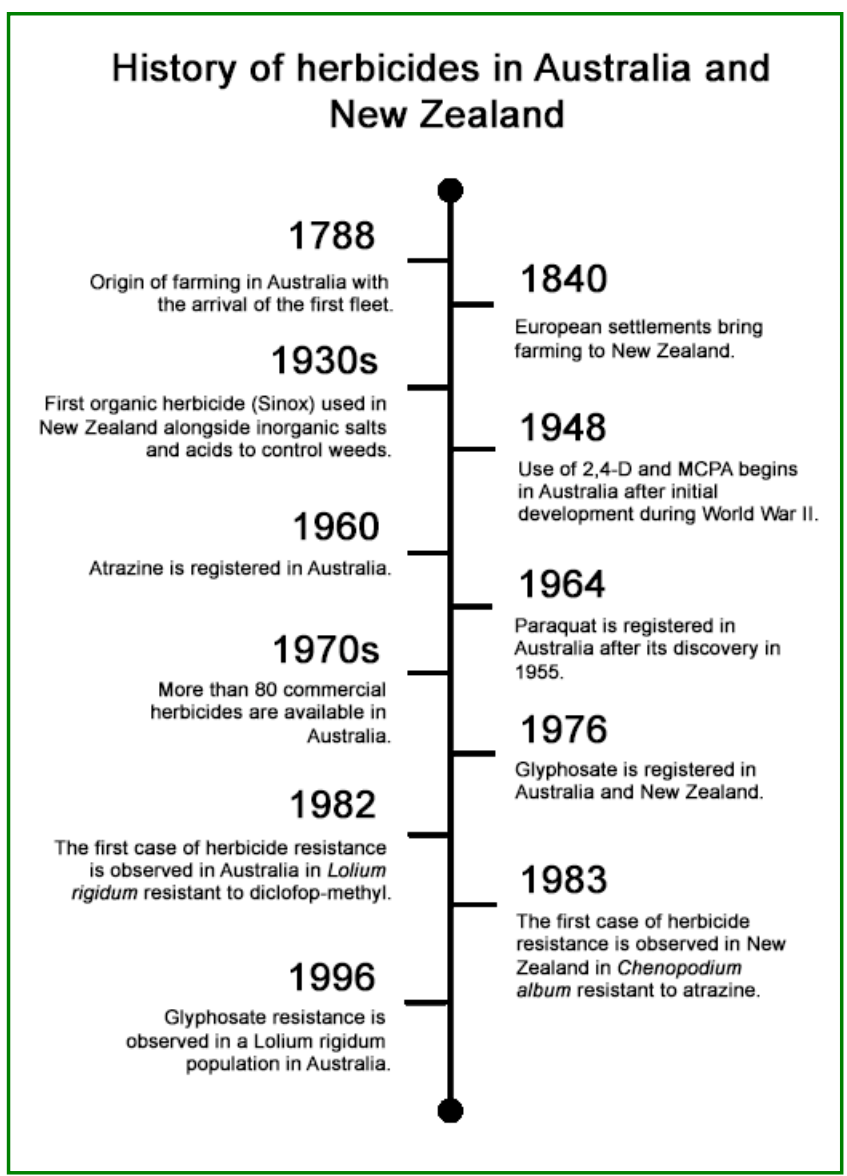

Figure 1 - History of herbicides in Australia and New Zealand land in Australia (Iqbal et al., 2019). However, increased reliance on glyphosate and other herbicides has led to the selection and evolution of herbicide-resistant weeds.

\section{Overview of cropping systems and herbicide use in Australia and New Zealand}

Since the arrival of European settlers, much of the landscape of Australia and New Zealand has changed to allow the growth of crops and pasture. Crops have often been grown in rotation with pasture as a form of weed control; however, in Australia pastures have been used less in recent years, while rotations with crops possessing greater weed control options increase in use (Harries et al., 2020). The Australian and New Zealand agriculture industries share commonalities but also vary in certain aspects due to the differences in climate and landscape between the countries.

Application of herbicides in these different cropping systems is determined by the specific situation of each production system. For example, in Australian wheat cropping, where no or reduced tillage is commonly practiced, pre-emergence herbicides can be effective. No-till allows higher soil moisture retention which is needed for proper activation of pre-emergence herbicides (Department of Primary Industries, 2012). Pre-emergence herbicides are often relied upon in grain cropping systems due to the increase in resistant weeds (e.g., L. rigidum) to post-emergence herbicides, such as acetyl CoA carboxylase (ACCase) and acetolactate synthase (ALS) inhibitors (Owen et al., 2014). Post-emergence herbicides can be effective tools for weed control; however, weeds tend to evolve resistance to these herbicides at a much faster pace than to pre-emergence herbicides, despite the frequent application of pre-emergence herbicides (Somerville et al., 2017). Pre-emergence herbicides are typically selective, targeting specific weeds. Trifluralin, for example, has been a commonly used selective pre-emergence herbicide in Australia for the control of grasses and broadleaf weeds in wheat (Boutsalis et al., 2014).

Glyphosate is a non-selective herbicide that is used as post-emergence herbicide throughout Australian and New Zealand cropping systems. In Australia, glyphosate is heavily used in fallows to control weeds prior to seeding, but is also used in 'double-knock' strategies alongside other non-selective herbicides paraquat and diquat, which helps to reduce glyphosate resistance by killing surviving weeds from the initial glyphosate application (Beckie et al., 2020). Glyphosate is applied directly to plants as it lacks soil residual activity (Baylis, 2000).

Glyphosate resistance has evolved in populations of $E$. colona in Western Australia as well as areas of the northern grain region of Australia (Goh et al., 2018; Mahajan et al., 2020). Resistance to glyphosate is also present in some populations of Erigeron bonariensis from the northeast cropping region (Walker et al., 2011). In addition to 
glyphosate resistance, Erigeron. bonariensis in Victoria has also shown resistance to chlorsulfuron, metsulfuronmethyl, and sulfometuron-methyl (Aves et al., 2020).

Some herbicides have a residual activity where they remain active in the soil for a period of time after application. These herbicides can be effective for killing emerging weeds, but care must be taken to ensure that the selected herbicide does not persist in the soil to damage future crops. Certain herbicides may persist longer in a particular soil type, such as sulfonylureas persisting longer in alkaline soils, while dry conditions can also prevent breakdown of residual herbicides (Hollaway et al., 2006b). Common maize residual herbicides used in New Zealand, for example, vary in residual activity between soil types, but heavy rainfall is sufficient to reduce most activity (Rahman et al., 2011).

\section{Challenges for sustainable use of herbicides in Australia} and New Zealand

\subsection{Overview of weed resistance}

Since the discovery of $2,4-\mathrm{D}$ in the 1940 s, herbicides have become the most relied upon form of weed control throughout the world. As more herbicides with different modes of action were developed, they became a highly effective form of weed control that was highly needed at a time when the labor market for manually removing weeds was drying up. However, overreliance on this form of control led to the development of herbicide-resistant weeds, which has now become a major global issue in agriculture, including in both Australia and New Zealand.

The first case of herbicide resistance in Australia was identified in L. rigidum. Heap and Knight (1982) reported the first case of resistant L. rigidum in 1982, which was resistant to the ACCase inhibiting herbicide diclofopmethyl. The first case of herbicide resistance in New Zealand was reported a year later in 1983 by Rahman et al. (1983), who observed atrazine resistance in the weed Chenopodium album. Since these initial reports of herbicide resistance, the number of cases has increased rapidly, making herbicide use an ineffective strategy in some fields without integration of other control methods.

Herbicide resistance has become a large problem globally; however, most cases have been reported from developed countries. Australia has long been one of the countries with the highest cases of herbicide-resistant weeds. In 1997, Heap (1997) reported on the global occurrences of herbicide resistance, where Australia had the fourth most number of herbicide-resistant unique cases alongside Canada, only two biotypes behind the second and third highest countries, France and Spain. At this time, New Zealand had also increased in the number of herbicide-resistant biotypes since the first case identified in 1983 but to a lesser extent than Australia, with five biotypes reported by Heap (1997). By 1997, herbicide resistance in Australian weeds had developed to a variety of modes of action. This included resistance to ALS inhibitors (nine species including B. tournefortii, Sonchus oleraceus, and L. rigidum), ACCase inhibitors (four species including Avena fatua, Digitaria sanguinalis, and $L$. rigidum), and amitrole (L. rigidum).

Despite the global importance of glyphosate, Australia was the only country with a report of resistance to this herbicide, with a population of L. rigidum showing resistance in 1996 (Heap, 1997; Pratley et al., 1999). This resistant $L$. rigidum population developed resistance in an apple orchard with a 15-year history of glyphosate use (Pratley et al., 1999). Until this report, glyphosate had been in use for at least 20 years without reports of resistance. As such, glyphosate was regarded as a safe herbicide to use for a broad spectrum of weeds due to a low risk of resistance developing from selection pressure.

Herbicide resistance is a major issue in Australian cropping systems. Out of all the weed species in Australia developing resistance, $L$. rigidum stands above all others with the number of populations with resistance. In fact, in many regions around Australia, most populations of $L$. rigidum possess resistance to at least one herbicide MOA. (Broster et al., 2019) screened 5308 samples of L. rigidum for herbicide resistance between 1991 and 2015, including samples from New South Wales, Western Australia, Victoria, South Australia, and Tasmania, and observed that only $19 \%$ of samples were susceptible to all tested herbicides. They found the highest rate of resistance occurred for Group 1 fop herbicides and pinoxaden (81\%), followed by Group 2 herbicides (56\%). Research has also found that the type of cropping system can affect resistance evolution in L. rigidum. For example, a negative association was found between tillage and ACCase/ALS inhibiting herbicide resistance, while increasing the proportion of wheat sown increased herbicide resistance (Broster et al., 2019). Llewellyn et al. (2016) estimated that herbicide-resistant $L$. rigidum increased herbicide costs by AU $\$ 103$ million annually.

In 2014, the number of herbicide-resistant weeds in Australia had risen to 62 , making Australia second only to the United States (144) for the most herbicide-resistant weeds (Heap, 2014). Raphanus raphanistrum is another of the costliest weeds in Australia for winter cereals, with resistance to the ALS inhibiting herbicide chlorsulfuron found in populations across the Western Australian Wheat belt (Walsh et al., 2001). Further resistance to 2,4-D, diflufenican, and atrazine has also been identified (Goggin et al., 2016; Lu et al., 2019; 2020). Other costly weeds of Australia in terms of herbicide resistance include A. fatua, Echinochloa colona, and Chloris virgata. Resistance to the ACCase inhibiting herbicide diclofop-methyl has been observed throughout populations of Avena spp. in Western Australian grain regions (Owen, Powles, 2009), with further resistance to haloxyfop also identified (Hassanpour-Bourkheili et al., 2021). 
Herbicide resistance in New Zealand has also increased since atrazine-resistant Chenopodium album was reported in 1983, although to a lesser extent than Australia. In the years following, the resistant $C$. album biotype spread from maize into asparagus fields, and three more weed species were identified as possessing some degree of herbicide resistance (Rahman, 1990). These included biotypes of Persicaria persicaria, which were also found to be resistant to atrazine and had been found in maize crops for the previous decade, as well as a population of Carduus nutans, which was reported with resistance to MCPA in 1987 (Rahman, 1990). Additionally, a population of Ranunculus acris was also reported as resistant to MCPA in 1988 (Bourdôt, Hurrell, 1988; Rahman, 1990). The latter two weeds are both pasture weeds in New Zealand, reflecting New Zealand's focus on animal agriculture as opposed to monoculture cropping.

After these initial cases of herbicide resistance in New Zealand, a further two cases were reported in 1996, followed by four more cases by the mid-2000s, before reaching a cumulative total of 25 reports of herbicide resistance in 2019 (Ghanizadeh, Harrington, 2019b). Herbicide-resistant weeds have been found in an array of cropping situations in New Zealand, including in both arable and horticultural crops, as well as in pasture.

Populations of $C$. album have developed resistance to multiple herbicides in maize crops, including multiple resistance to both dicamba and atrazine in some populations (Ghanizadeh, Harrington, 2019a) and dicamba and auxinic herbicides (aminopyralid and picloram) in others (Ghanizadeh and Harrington 2017). Multiple resistance has also occurred in the pasture weed $R$. acris, where plants were found to be resistant to both flumetsulam and MCPA (ALS and phenoxycarboxylic acid inhibitor herbicides, respectively) (Jackman et al., 2020). Glyphosate resistance has been found in vineyards in New Zealand (Ghanizadeh et al., 2015a). Furthermore, in some GR populations of L. perenne and L. multiflorum, researchers identified additional resistance to glufosinate and amitrole (Ghanizadeh et al., 2015b). Therefore, not only has herbicide resistance been observed in arable and horticultural crops, and pasture, but resistance to multiple herbicide modes of action has also been observed.

Australia also has a high frequency of multiple herbicide resistance developing in resistant populations. In the survey by Broster et al. (2019), 57\% of the 3390 samples screened for resistance to multiple herbicides showed resistance to two or more groups/subgroups of herbicides. Research by Owen et al. (2015) identified 77 out of 96 populations analyzed had resistance to multiple herbicide modes of action. Additionally, $C$. bonariensis has been identified with multiple resistance to glyphosate, chlorsulfuron, metsulfuron-methyl, and sulfometuron-methyl in five out of nine populations analyzed (Aves et al., 2020).

\subsection{Use of integrated weed management}

Herbicides have long been the dominant form of weed control in Australia and New Zealand; however, with the advent of herbicide resistance, in addition to concerns for human and environmental health, there has been a need for new directions in weed control. IWM strategies strive to reduce reliance on herbicides by combining different forms of weed control. As no new herbicide MOA has been developed and marketed for around 30 years, other non-chemical methods are needed. Types of non-chemical methods that are used as part of IWM in Australia and New Zealand are varied and include biological controls (e.g., insects or plant pathogens), harvest weed seed control (HWSC), grazing, crop rotation, cover crops, and time of sowing, in addition to others.

Implementing control methods other than herbicide use into IWM strategies increases short-term costs to growers. Therefore, in many cases, growers are hesitant to adopt these strategies and pay the additional costs. Growers often want short-term results; however, IWM usually targets long term success of weed control, such as in a study in Western Australia by Borger et al. (2016) which reduced L. rigidum seed density to an average of 0 seeds $\mathrm{m}^{-2}$ over the course of 11 years by implementing HWSC and narrow row spacing alongside herbicide application. The techniques used in that study are also relatively inexpensive and may be more likely to be taken up by growers.

Adoption of IWM by Australian growers is often driven by the identification of herbicide resistance in their fields, which sparks the necessity for other control methods as herbicides become less effective (Grains Research and Development Corporation, 2019). In 2000, IWM practices in Western Australia were adopted more, on average, by growers with herbicide resistance on their farm, with some types of IWM practices having higher rates of adoption than others depending on the presence of herbicide resistance, such as crop-topping (Llewellyn et al., 2004). Growers with herbicide resistance on their farm used 8.4 types of IWM practices on average, compared to growers without resistance, who used 6.6 IWM practices on average.

Improved crop competition is a core component of IWM in Australia, which includes the selection of competitive cultivars, narrow row spacing, row orientation, and sowing crops at higher densities (Bajwa et al., 2017). Choice of a crop has also improved weed management in Western Australia, whereby certain crops have better options for weed control; however, this has led to lower diversity in land use (Harries et al., 2020).

A survey of 600-grain growers across Australia in 2014 identified that adoption of HWSC techniques had increased in prevalence, with nearly half (43\%) of all growers using some form of HWSC (Walsh et al., 2017b). The main type of HWSC used by growers was narrow-windrow burning, which had been adopted by $30 \%$ of the surveyed growers. 
The use of HWSC has proven effective at reducing the seedbank input of L. rigidum in grain-growing regions of Australia, resulting in average reductions of around $60 \%$, with similar reductions observed for different types of HWSC (Chaff cart, narrow-windrow burning, and Harrington seed destructor) (Walsh et al., 2017a). As such, HWSC can be an important component of IWM for controlling the seedbank, which could work alongside herbicide programs as well as other techniques focusing on preventing the growth of weeds.

In New Zealand pastures, grazing management can allow pasture plants to remain competitive against weeds. The degree of success is determined by grazing time, intensity, and pressure, as well as the type and amount of animal used for grazing (Ghanizadeh, Harrington, 2019c). Further improving crop competitiveness also contributes to successful weed management, through selecting more competitive plant species (Wardle et al., 1995) and optimizing the environmental conditions (Eerens et al., 2002). Using these strategies in combination with others is important as biotic and abiotic stresses can allow space for weeds to establish (Ghanizadeh, Harrington, 2019c). Biological control methods using insects and pathogens (classical control) or bio-herbicides are also used in New Zealand and can be implemented as part of an IWM strategy (Bourdôt et al., 2007). However, the effectiveness of these biological controls has not yet been fully realized in field crops and further research is required.

With the absence of new herbicide modes of action emerging onto the market, IWM will become increasingly important as more populations of weeds evolve resistance to herbicides. In the future, IWM systems will be able to take advantage of new research and potential new technologies. This may take the form of new biological controls as our understanding of plant-pathogen interactions increases or the use of sensors, GPS, and robots as a part of site-specific weed management. However, the main requirements that need to be satisfied to achieve greater adoption of IWM strategies are to be low in cost and to produce results in weed control over the short-term rather than the long-term.

\subsection{Herbicide banning}

Herbicides have maintained their position as the dominant form of weed control ever since their introduction. However, in recent years there have been increased concerns over the effect of herbicides on the health of humans, animals, and the environment. As such, discussions around banning various herbicides have been held in many countries, with some countries ultimately banning specific herbicides from use. While herbicides banned in other countries are still in use, this may change in Australia and New Zealand as this issue continues to be discussed and as regulations in other countries affect Australian and New Zealand exports.
The use and effectiveness of some herbicides in Australia and New Zealand are already under threat from weeds developing resistance. Potential legislative restrictions on the use of these herbicides then would put increasing pressure on identifying alternate strategies for weed control. The world's most widely used herbicide, glyphosate, has been banned or had restrictions placed on its use in a number of countries in recent years (Baum Hedlund Law, 2021). Concern over the carcinogenic effect of glyphosate has been largely stoked by legal cases in the United States over claims of non-Hodgkin Lymphoma caused by the herbicide. A study by Zhang et al. (2019) observed via a meta-analysis that the meta-relative risk of non-Hodgkin Lymphoma increased by $41 \%$ due to glyphosate-based herbicides. Additionally, in 2015, glyphosate was classified as probably carcinogenic to humans (Group 2A) by the International Agency for Research on Cancer (IARC) in addition to finding sufficient evidence of carcinogenicity in experimental animals (https://publications.iarc.fr/549). However, since this report, the Australian Pesticides and Veterinary Medicines Authority (APVMA) reviewed their assessment but did not place it under formal reconsideration, stating in 2017 that exposure to glyphosate does not pose a carcinogenic or genotoxic risk to humans (Australian Pesticides \& Veterinary Medicines Authority, 2017). While there is currently no Australia-wide ban on glyphosate, a number of localities have placed restrictions on its use. Glyphosate is also used in New Zealand, being approved for use by the Environmental Protection Authority, which stated that glyphosate is unlikely to be genotoxic or carcinogenic to humans and does not require classification as a carcinogen or mutagen (Temple, 2016). However, without long-term evidence on the effect of glyphosate on human physiology, the public concern will remain as exposure to glyphosate comes not only during spraying of the herbicide but in food derived from the sprayed crops (Myers et al., 2016).

Another herbicide often involved in discussions around herbicide banning is paraquat, a compound that diverts electron from photosynthesis to form highly toxic radicals. Paraquat is a quick-acting and non-selective contact herbicide used as a broad-spectrum herbicide of many grass and broadleaf weeds (Lock, Wilks, 2010). It is highly effective at killing plants, but is also known to be highly toxic to humans. Ingestion of paraquat causes organ failure and subsequently death, and poisoning with this herbicide results in the highest rate of mortality of all pesticides (Davarpanah et al., 2015). In South Korea, paraquat was commonly used as a method of suicide prior to its prohibition (Myung et al., 2015). As paraquat is known to be highly lethal, it has been classed as a schedule 7 chemical in Australia, which means it can only be purchased by those with an agricultural chemical user permit. As of 2021, paraquat is undergoing a review by the APVMA. In New Zealand, paraquat is only approved for use in agricultural, as well as for biosecurity purposes on condition of obtaining 
permission. However, some products containing paraquat have been banned and restrictions have been placed on the application rate and spray droplet size (Environmental Protection Authority, 2019).

Prohibiting herbicides can have unwanted outcomes on the Australian and New Zealand agricultural industries. Banning specific herbicides can result in growers increasing the use of another herbicide, which puts greater selection pressure on weeds to develop resistance to that herbicide, whereas alternating between herbicides can help to reduce the selection pressure. Herbicide bans could affect exports if it leads to lower weed control, as the number of weed seeds in exports may be greater than the importing country's standards. On the other hand, if herbicides remain in use, care must be taken to ensure that herbicide residue levels remain below the maximum residue levels of importing countries. As more countries ban specific herbicides, this may force other countries to ban those same herbicides or put in place tighter regulations to ensure their exports are unaffected.

\subsection{Other challenges}

Proper application of herbicides is crucial for ensuring the effectiveness of herbicides and avoiding undesirable outcomes in weed control programs. A lot of responsibility is placed on farmers to choose appropriate herbicide options and correctly apply the herbicide in the field. Following herbicide-label instructions ensures safe application; however, human error and inexperience may cause issues for the user and the environment or decrease the effectiveness of the herbicide if applied at the wrong time. Similarly, safe herbicide use also requires the user to follow strict storage directions, so that herbicides are stored in their correct containers at an appropriate temperature to protect the user and the environment. Correct disposal of herbicide containers also ensures potential environmental detriments are minimized or avoided.

The impact on the environment is one of the main concerns surrounding herbicide use. Persistence of herbicides past the time of their intended use can lead to undesired effects on the environment as well as subsequent crops. The length of time it takes for herbicides to be broken down in the soil is influenced by soil factors such as composition, chemistry, and microbial activity, as well as climatic factors such as moisture, temperature, and sunlight (Curran, 2016). For example, atrazine and trifluralin could persist for a few years in clay loam soils at temperatures lower than $20{ }^{\circ} \mathrm{C}$ (Chowdhury et al., 2021). Persistence of herbicides in the soil also has an effect on the microbial communities in the soil. Bacterial composition in soil changes over time with herbicide exposure, with the type of herbicide also affecting composition (Moretto et al., 2017). Glyphosate, glufosinate, and dicamba have increased the occurrence of antibiotic resistance genes and mobile genetic elements in soil microbial communities (Liao et al., 2021). Transfer of these genes between bacteria was also found, whereby herbicides increased conjugation of multidrug resistance plasmids (Liao et al., 2021).

Herbicide leaching leads to movement of herbicides deeper into the soil profile and can contaminate groundwater (Gaw et al., 2008; Hollaway et al., 2006a). Herbicides were the most common pesticide detected in groundwater in a study by Gaw et al. (2008) who tested 163 wells across 14 regions of $\mathrm{New}$ Zealand. Additionally, glyphosate has been detected in urban surface waters in Australia. Okada et al. (2020) identified the presence of glyphosate in $77 \%$ of urban stormwater wetlands and $79 \%$ of urban streams, demonstrating the potential for contamination of non-target environments. Herbicides are also one of the main types of pollutants affecting the Great Barrier Reef in Australia (Brodie et al., 2012). Protecting our waterways from herbicide contamination is a crucial consideration for sustainable farming.

Herbicides may also drift from the intended target to nearby water or vegetation, including crops. This can cause environmental contamination and crop deaths. Spray drift is affected by various factors such as wind direction and speed, air stability and relative humidity, mode of application, and droplet size (Felsot et al., 2010). Spray drift from non-selective herbicides, such as glyphosate, may be particularly damaging to surrounding vegetation as they affect a wide array of plants (Florencia et al., 2017). Herbicides have been detected in air and rain samples, including glyphosate, trifluralin, atrazine, and metolachlor; however, most glyphosate is removed from the air with sufficient rain (Chang et al., 2011; Majewski et al., 2008). Low doses of herbicides, as can occur with herbicide drift, can result in hormesis of weeds, leading to improved growth and seed production (Mobli et al., 2020; Mollaee et al., 2020). Hormesis from herbicides may also result in increased resistance by increasing the fitness of resistant plants and favor higher seed production in resistant plants compared to susceptible plants (Belz, 2018).

In addition to crop deaths, herbicides can also be lethal to beneficial insects in crops and the environment. Herbicide application has had varying effects on lady beetles, with up to $80 \%$ mortality after 2,4-D application (Freydier, Lundgren, 2016). Application of a combination of herbicides reduced larvae body size and selectively killed males. Exposure of earthworms to 2,4-D for 14 days resulted in $30-40 \%$ mortality at $10 \mathrm{mg} / \mathrm{kg}$ soil, while 500 $\mathrm{mg} / \mathrm{kg}$ soil led to $100 \%$ mortality after exposure for a few hours (Correia, Moreira, 2010). Glyphosate transfer from honey bees to hive compartments has been detected, as well as a change in gut microbiota in honey bees with oral or topical exposure to a glyphosate formulation (Motta et al., 2020). As insects are a core component of flourishing ecosystems, ensuring the sustainability of beneficial insect populations in Australia and New Zealand is a challenge that must be met. 


\section{Perspective of sustainable weed management}

As the global population continues to grow, food production will need to increase to meet the growing demand. Weeds will continue to be one of the major constraints on global food production. As such, weed management must continue to be improved to minimize weeds' impacts on yield loss. The future of weed management is expected to change in the coming decades as new research provides a better understanding of weed ecology and novel technologies allow more specific and efficient weed management options.

Herbicides remain the most dominant form of weed control. As such, there is a great need for herbicides with new modes of action to combat herbicide-resistant weeds. However, due to the challenges of developing and releasing a new herbicide to the market, this cannot be relied upon for future weed control. The development of RNA interference technology, such as BioDirect ${ }^{\mathrm{TM}}$ by Monsanto, could be a way to deal with resistance by suppressing expression of the target gene (e.g., EPSPS) (Shaner, Beckie, 2014).

The evolution of herbicide resistance in many weed species to a wide variety of herbicide modes of action has shown that without herbicides with new modes of action emerging onto the market, herbicides will decline in their overall effectiveness as a weed control agent. Research into management strategies that minimize the rate of resistance evolution in weeds will be necessary for maintaining the effectiveness of current herbicides.

Improved IWM strategies could help farmers control herbicide-resistant weeds. Sufficient research into IWM strategies will be important for giving farmers confidence in implementing them where they may incur large shortterm costs that would otherwise lead them to dismiss IWM. Further research on effective crop rotations to reduce resistance evolution is also needed. However, if crop rotations identified as beneficial for resistance control lead to lower profits for growers, there may be low adoption of these rotations without sufficient incentives.

Hand weeding was often used to controlweeds in developed countries in the past; however, due to labor shortages and the large areas of crop production, this is not currently a feasible option. To overcome this limitation, engineering companies have recently been developing robotics for weed control. For example, robots capable of mapping weeds in lettuce by realtime identification of crops and weeds have been developed, which also employ a micro-jet herbicide spraying system for precise herbicide application (Raja et al., 2020). This system was capable of $99.75 \%$ crop detection accuracy and $98.11 \%$ detection of sprayable weeds. Weed and crop identification is crucial for effective robotic weed control. As such, improved machine learning algorithms will be needed. Intelligent mechanical intra-row weeding has also been developed for use in cabbage, where it was capable of controlling 50-90\% of intra-row weeds without harming the crop (Melander et al., 2015). As these types of technologies continue to develop, they will reduce the need for manual removal of weeds as well as other forms of weed control. However, high costs associated with these systems may make them unavailable to many farmers. Therefore, reliance on traditional weed control methods will remain.

Training emerging weed scientists will also be important for the future of weed control in Australia and New Zealand. As weed control continues to include a wider array of options and technologies, it will be necessary to ensure weed scientists have diverse training to ensure that they are well versed in the many potential future technologies and basic weed biology and ecology.

\section{Conclusions}

The use of herbicides in Australia and New Zealand has become the dominant form of weed control since their emergence in the market in the 1940s, with a range of herbicides with different modes of action becoming available in the following decades to control a broad spectrum of weeds. This shift in weed control methods forced growers to learn new skills and equipment for applying the chemicals, but the increasing reliance on herbicides resulted in herbicideresistant weeds throughout agricultural lands in Australia and New Zealand. IWM assists growers to incorporate multiple non-chemical weed control methods in combination with herbicides to reduce the risk of resistance evolution, with HWSC being one of the main forms of weed control used by growers in Australia. As concerns over the safety of common herbicides, such as glyphosate, increase the potential for the removal of selected herbicides from the market may force growers to adopt IWM strategies. Future weed control will likely make use of robotics in combination with herbicides for more precise weed management; however, other unforeseen technologies may provide non-herbicide alternatives. It will also be necessary for new research to continue to identify the most effective forms of weed control for specific weeds and environments.

\section{Author's contributions}

MT, and BC: conceptualization of the manuscript and development of the methodology. BC: funding acquisition and resources. MT: writing the original draft of the manuscript. MT, and BC: writing, review and editing. All authors read and agreed to the published version of the manuscript.
Australian Pesticides \& Veterinary Medicines Authority - Apvma. Atrazine final review report and regulatory decision. Canberra: Australian
Pesticides \& Veterinary Medicines Authority; 2008 [access May 15, 2021]. Available from: https://apvma.gov.au/node/14361 
Australian Pesticides \& Veterinary Medicines Authority - Apvma. Final regulatory position: consideration of the evidence for a formal reconsideration of glyphosate. Canberra: Australian Pesticides \& Veterinary Medicines Authority; 2017 [access May 15, 2021]. Available from: https://apvma.gov.au/node/26561

Australian Pesticides \& Veterinary Medicines Authority - Apvma. Glyphosate. Canberra: Australian Pesticides \& Veterinary Medicines Authority; 2019 [access May 15, 2021]. Available from: https://apvma.gov.au/node/13891

Australian Pesticides \& Veterinary Medicines Authority - Apvma. Paraquat toxicology report: summary. Canberra: Australian Pesticides \& Veterinary Medicines Authority; 2016 [access May 15, 2021]. Available from: https://apvma.gov.au/node/20766

Aves C, Broster J, Weston L, Gill GS, Preston C. Conyzo bonariensis (flax-leaf fleabane) resistant to both glyphosate and ALS inhibiting herbicides in north-eastern Victoria. Crop Past Science. 2020;71(9):86471. Available from: https://doi.org/10.1071/CP19537

Bajwa AA, Walsh M, Chauhan BS. Weed management using crop competition in Australia. Crop Prot. 2017;95:8-13. Available from: https:// doi.org/10.1016/j.cropro.2016.08.021

Baum Hedlund Law. Where Is glyphosate banned? Monsanto Roundup Lawsuit. 2021. Available from: https://www.baumhedlundlaw.com/ toxic-tort-law/monsanto-roundup-lawsuit/where-is-glyphosatebanned-l.

Baylis AD. Why glyphosate is a global herbicide: strengths, weaknesses and prospects. Pest Manage Sci. 2000;56(4):299-308. Available from: https://doi.org/10.1002/(SICI)1526-4998(200004)56:4<299::AIDPS144>3.0.CO;2-K

Beckie HJ, Flower KC, Ashworth MB. Farming without Glyphosate? Plants. 2020;9(1):1-15. Available from: https://doi.org/10.3390/ plants9010096

Belz RG. Herbicide hormesis can act as a driver of resistance evolution in weeds: PSII-target site resistance in Chenopodium album L. as a case study. Pest Manage Sci. 2018;74(12):2874-83. Available from: https://doi.org/10.1002/ps.5080

Borger CPD, Riethmuller G, D'Antuono M. Eleven years of integrated weed management: long-term impacts of row spacing and harvest weed seed destruction on Lolium rigidum control. Weed Res. 2016;56(5):359-66. Available from: https://doi.org/10.1111/wre.12220

Bourdôt G, Hurrell G, editors. Differential tolerance of MCPA among giant buttercup (Ranunculus acris) biotypes in Takaka, Golden Bay. Proc N Z Weed Pest Control Conf. 1988;41:231-4. Available from: https://doi. org/10.30843/nzpp.1988.41.9859

Bourdôt GW, Fowler SV, Edwards GR, Kriticos DJ, Kean JM, Rahman $A$ et al. Pastoral weeds in New Zealand: status and potential solutions. N Z J Agric Res. 2007;50(2):139-61. Available from: https://doi. org/10.1080/00288230709510288

Boutsalis P, Gill GS, Preston C. Control of rigid ryegrass in australian wheat production with pyroxasulfone. Weed Technol. 2014;28(2):3329. Available from: https://doi.org/10.1614/WT-D-13-00094.1
Brodie JE, Kroon FJ, Schaffelke B, Wolanski EC, Lewis SE, Devlin MJ et al. Terrestrial pollutant runoff to the great barrier reef: an update of issues, priorities and management responses. Mar Pollut Bull. 2012;65(4):81100. Available from: https://doi.org/10.1016/j.marpolbul.2011.12.012

Broster JC, Pratley JE, Ip RHL, Ang L, Seng KP. A quarter of a century of monitoring herbicide resistance in Lolium rigidum in Australia. Crop Past Sci. 2019;70(3):283-93. Available from: https://doi.org/10.1071/ CP18584

Broster JC, Pratley JE, Ip RHL, Ang L, Seng KP. Cropping practices influence incidence of herbicide resistance in annual ryegrass (Lolium rigidum) in Australia. Crop Past Sci. 2019;70(1):77-84. Available from: https://doi.org/10.1071/CP18355

Chang FC, Simcik MF, Capel PD. Occurrence and fate of the herbicide glyphosate and its degradate aminomethylphosphonic acid in the atmosphere. Environ Toxicol Chem. 2011;30(3):548-55. Available from: https://doi.org/10.1002/etc.431

Chowdhury IF, Rohan M, Stodart BJ, Chen C, Wu H, Doran GS. Persistence of atrazine and trifluralin in a clay loam soil undergoing different temperature and moisture conditions. Environ Pollut. 2021;276:110. Available from: https://doi.org/10.1016/j.envpol.2021.116687

Correia FV, Moreira JC. Effects of glyphosate and 2,4-D on earthworms (Eisenio foetida) in laboratory tests. Bull Environ Contam Toxicol. 2010;85(3):264-8. Available from: https://doi.org/10.1007/ s00128-010-0089-7

Curran WS. Persistence of herbicides in soil. Crops Soils. 2016;49(5):16-21.

Davarpanah MA, Hosseinzadeh F, Mohammadi SS. Treatment following intoxication with lethal dose of paraquat: a case report and review of literature. Iran Red Crescent Med J. 2015;17(10):1-4. Available from: https://doi.org/10.5812/ircmj.19373

Department of Primary Industries - DPI. Using pre-emergent herbicides in conservation farming systems. Sidney: Department of Primary Industries; 2012 [access May 15, 2021]. Available from: https://www. dpi.nsw.gov.au/agriculture/broadacre-crops/winter-crops/general-information/pre-emergent-herbicides.

Department of Primary Industries and Regions South Australia - Pirsa. Weed control in the south australian wheat industry. Canberra: Department of Primary Industries and Regions South Australia; 2017 [access May 15, 2021]. Available from: https://www.pir.sa.gov.au/aghistory/industries/cereals__and__grains/wheat/weed_control

Duke SO, Powles SB. Glyphosate: a once-in-a-century herbicide. Pest Manage Sci. 2008;64(4):319-25. Available from: https://doi. org/10.1002/ps.1518

Eerens J, Rahman A, James T. Optimising pasture production to minimise weed growth. Proc N Z Grass Assoc. 2002;54:1-4. Available from: https://doi.org/10.33584/jnzg.2002.64.2451

Environmental Protection Authority - EPA. Glyphosate New Zealand. Wellington: Environmental Protection Authority; 2021 [access May 16, 2021]. Available from: https://www.epa.govt.nz/everyday-environment/gardening-products/glyphosate/ 
Environmental Protection Authority - EPA. Rules for paraquat use New Zealand. Wellington: Environmental Protection Authority; 2019 [access May 16, 2021]. Available from: https://www.epa.govt.nz/news-andalerts/alerts/rules-for-paraquat-use/

Felsot AS, Unsworth JB, Linders JBHJ, Roberts G, Rautman D, Harris $C$ et al. Agrochemical spray drift; assessment and mitigation: a review. J Environ Sci Health B. 2010;46(1):1-23. Available from: https://doi.org/ 10.1080/03601234.2010.515161

Florencia FM, Carolina T, Enzo B, Leonardo G. Effects of the herbicide glyphosate on non-target plant native species from Chaco forest (Argentina). Ecotoxicol Environ Saf. 2017;144:360-8. Available from: https://doi.org/10.1016/j.ecoenv.2017.06.049

Freydier L, Lundgren JG. Unintended effects of the herbicides 2,4-D and dicamba on lady beetles. Ecotoxicology. 2016;25(6):1270-7. Available from: https://doi.org/10.1007/s10646-016-1680-4

Gaw S, Close ME, Flintoft MJ. Fifth national survey of pesticides in groundwater in New Zealand. N Z J Mar Freshwat Res. 2008;42(4):397407. Available from: https://doi.org/10.1080/00288330809509968

Ghanizadeh H, Harrington KC, James TK, Woolley DJ, Ellison NW. Mechanisms of glyphosate resistance in two perennial ryegrass (Lolium perenne) populations. Pest Manage Sci. 2015b;71(12):1617-22. Available from: https://doi.org/10.1002/ps.3968

Ghanizadeh H, Harrington KC, James TK. Glyphosate-resistant Lolium multiflorum and Lolium perenne populations from New Zealand are also resistant to glufosinate and amitrole. Crop Prot. 2015a;78:1-4. Available from: https://doi.org/10.1016/j.cropro.2015.08.008

Ghanizadeh $H$, Harrington KC. Cross-resistance to auxinic herbicides in dicamba-resistant Chenopodium album. N Z J Agric Res. 2017;60(1):45-53. Available from: https://doi.org/10.1080/00288233. 2016.1238397

Ghanizadeh $\mathrm{H}$, Harrington KC. Fitness costs associated with multiple resistance to dicamba and atrazine in Chenopodium album. Planta. 2019a;249(3):787-97. Available from: https://doi.org/10.1007/ s00425-018-3040-5

Ghanizadeh H, Harrington KC. Herbicide resistant weeds in New Zealand: state of knowledge. N Z J Agric Res. 2019b;64(4):1-12. Available from: https://doi.org/10.1080/00288233.2019.1705863

Ghanizadeh $\mathrm{H}$, Harrington KC. Weed management in New Zealand pastures. Agronomy. 2019c;9(8):1-18. Available from: https://doi. org/10.3390/agronomy9080448

Goggin DE, Cawthray GR, Powles SB. 2,4-D resistance in wild radish: reduced herbicide translocation via inhibition of cellular transport. J Exp Bot. 2016;67(11):3223-35. Available from: https://doi.org/10.1093/ jxb/erw120

Goh SS, Yu Q, Han H, Vila-Aiub MM, Busi R, Powles SB. Non-target-site glyphosate resistance in Echinochloo colono from western Australia. Crop Prot. 2018;112:257-63. Available from: https://doi.org/10.1016/j. cropro.2018.06.013

Grains Research and Development Corporation - GRDC. Integrated weed management. Canberra: Grains Research and Development Cor- poration; 2019 [access May 15, 2021]. Available from: https://www.lls. nsw.gov.au/__data/assets/pdf_file/0008/1218158/IWM2019-handbook-V4-AP.pdf

Green JM. The rise and future of glyphosate and glyphosate-resistant crops. Pest Manage Sci. 2018;74(5):1035-9. Available from: https://doi. org/10.1002/ps.4462

Harker KN, O'Donovan JT. Recent weed control, weed management, and integrated weed management. Weed Technol. 2013;27(1):1-11. Available from: https://doi.org/10.1614/WT-D-12-00109.1

Harries M, Flower KC, Scanlan CA, Rose MT, Renton M. Interactions between crop sequences, weed populations and herbicide use in Western Australian broadacre farms: findings of a sixyear survey. Crop Past Sci. 2020;71(5):491-505. Available from: https://doi.org/10.1071/CP19509

Hassanpour-Bourkheili S, Gherekhloo J, Kamkar B, Ramezanpour SS. Mechanism and pattern of resistance to some ACCase inhibitors in winter wild oat (Aveno sterilis subsp. ludoviciono (Durieu) Gillet \& Magne) biotypes collected within canola fields. Crop Prot. 2021;143. Available from: https://doi.org/10.1016/j.cropro.2021.105541

Heap IM. Global perspective of herbicide-resistant weeds. Pest Manage Sci. 2014;70(9):1306-15. Available from: https://doi. org/10.1002/ps.3696

Heap IM. International survey of herbicide resistant weeds. Weedscience. 2021[access Oct 06, 2021]. Available from: https://www. weedscience.org

Heap IM. The occurrence of herbicide-resistant weeds worldwide. Pestic Sci. 1997;51(3):235-43. https://doi.org/10.1002/(SICI)10969063(199711)51:3<235::AID-PS649>3.0.CO;2-N

Heap J, Knight R. A population of ryegrass tolerant to the herbicide diclofop-methyl [in South Australia]. J Aust Inst Agric Sci. 1982:48;156-7.

Hollaway KL, Kookana RS, Noy DM, Smith JG, Wilhelm N. Crop damage caused by residual acetolactate synthase herbicides in the soils of south-eastern Australia. Anim Prod Sci. 2006a;46(10):1323-31. Available from: https://doi.org/10.1071/EA05053

Hollaway KL, Kookana RS, Noy DM, Smith JG, Wilhelm N. Persistence and leaching of sulfonylurea herbicides over a 4-year period in the highly alkaline soils of south-eastern Australia. Aust $J$ Exp Agric. 2006b;46(8):1069-76. Available from: https://doi.org/10.1071/ EA04221

Iqbal N, Manalil S, Chauhan BS, Adkins SW. Glyphosate-tolerant cotton in Australia: successes and failures. Arch Agron Soil Sci. 2019;65(11):1536-53. Available from: https://doi.org/10.1080/036503 40.2019.1566720

Jackman S, Bourdôt GW, Noble A, Lamoureaux SL, Ghanizadeh H. Multiple resistance to flumetsulam and MCPA in two clones of Ronunculus ocris. N Z J Agric Res. 2020:1-15. Available from: https://doi.org/10.108 0/00288233.2020.1779755

Jugulam M, Shyam C. Non-target-site resistance to herbicides: recent developments. Plants. 2019;8(10):1-16. Available from: https://doi. org/10.3390/plants8100417 
Liao H, Li X, Yang Q, Bai Y, Cui P, Wen C et al. Herbicide Selection Promotes Antibiotic Resistance in Soil Microbiomes. Mol Biol Evol. 2021;38(6):2337-50. Available from: https://doi.org/10.1093/molbev/ msab029

Llewellyn R, Ronning D, Ouzman J, Walker S, Mayfield A, Clarke M. Impact of weeds on Australian grain production: the cost of weeds to australian grain growers and the adoption of weed management and tillage practices. Canberra: Grains Research \& Development Corporation; 2016.

Llewellyn RS, Lindner RK, Pannell DJ, Powles SB. Grain grower perceptions and use of integrated weed management. Austr $\mathrm{J}$ Exp Agric. 2004;44(10):993-1001. Available from: https://doi.org/10.1071/ EA03115

Lock EA, Wilks MF. Paraquat. In: Krieger R, editor. Hayes' handbook of pesticide toxicology. 3th ed. New York: Academic; 2010. p. 1771-827.

Lu H, Yu Q, Han H, Owen MJ, Powles SB. A novel psbA mutation (Phe274-Val) confers resistance to PSII herbicides in wild radish (Rophanus raphanistrum). Pest Manage Sci. 2019;75(1):144-51. Available from: https://doi.org/10.1002/ps.5079

Lu H, Yu Q, Han H, Owen MJ, Powles SB. Non-target-site resistance to PDS-inhibiting herbicides in a wild radish (Rophanus raphanistrum) population. Pest Manage Sci. 2020;76(6):2015-20. Available from: https://doi.org/10.1002/ps.5733

Mahajan G, Kaur V, Thompson M, Chauhan BS. Growth behavior and glyphosate resistance level in 10 populations of Echinochloo colono in Australia. PLoS One. 2020;15(1):1-13. Available from: https://doi. org/10.1371/journal.pone.0221382

Majewski MS, Foreman WT, Coupe RH, Goolsby DA, Wiebe FW. Pesticides in air and rainwater in the midcontinental United States, 1995: methods and data. Reston: US Geological Survey; 2008.

Manktelow D, Stevens P, Walker J, Gurnsey S, Park N, Zabkiewicz $\mathrm{J}$ et al. Trends in pesticide use in New Zealand: 2004. Wellington: Ministry for the Environment; 2005.

Melander B, Lattanzi B, Pannacci E. Intelligent versus non-intelligent mechanical intra-row weed control in transplanted onion and cabbage. Crop Prot. 2015;72:1-8. Available from: https://doi.org/10.1016/j.cropro.2015.02.017

Mobli A, Matloob A, Chauhan BS. Glyphosate-induced hormesis: impact on seedling growth and reproductive potential of common sowthistle (Sonchus oleraceus). Weed Sci. 2020;68(6):605-11. Available from: https://doi.org/10.1017/wsc.2020.77

Mollaee M, Matloob A, Mobli A, Thompson M, Chauhan BS. Response of glyphosate-resistant and susceptible biotypes of Echinochloo colono to low doses of glyphosate in different soil moisture conditions. PloS One. 2020;15(5):1-16. Available from: https://doi.org/10.1371/journal. pone.0233428

Moretto JAS, Altarugio LM, Andrade PA, Fachin AL, Andreote FD, Stehling EG. Changes in bacterial community after application of three different herbicides. FEMS Microbiol Lett. 2017;364(13):1-6. Available from: https://doi.org/10.1093/femsle/fnx113
Motta EVS, Mak M, Jong TKD, Powell JE, O'Donnell A, Suhr KJ et al. Oral or topical exposure to glyphosate in herbicide formulation impacts the gut microbiota and survival rates of honey bees. Appl Environ Microbiol. 2020;86(18):e01150-20. Available from: https://doi.org/10.1128/ AEM.01150-20

Myers JP, Antoniou MN, Blumberg B, Carroll L, Colborn T, Everett LG et al. Concerns over use of glyphosate-based herbicides and risks associated with exposures: a consensus statement. Environ Health. 2016;15(1):19. Available from: https://doi.org/10.1186/s12940-016-0117-0

Myung W, Lee GH, Won HH, Fava M, Mischoulon D, Nyer $M$ et al. Paraquat prohibition and change in the suicide rate and methods in South Korea. PLoS ONE. 2015;10(6):1-10. Available from: https://doi. org/10.1371/journal.pone.0128980

Neve P, Diggle AJ, Smith FP, Powles SB. Simulating evolution of glyphosate resistance in Lolium rigidum II: past, present and future glyphosate use in australian cropping. Weed Res. 2003;43(6):418-27. Available from: https://doi.org/10.1046/j.0043-1737.2003.00356.x

Norman A, Minarik C, Weintraub R. Herbicides. Ann Rev Plant Physiol. 1950;1(1):141-68. Available from: https://doi.org/10.1146/annurev. pp.01.060150.001041

Okada E, Allinson M, Barral MP, Clarke B, Allinson G. Glyphosate and aminomethylphosphonic acid (AMPA) are commonly found in urban streams and wetlands of Melbourne, Australia. Water Res. 2020;168:115139. Available from: https://doi.org/10.1016/j. watres.2019.115139

Owen MJ, Martinez NJ, Powles SB. Multiple herbicide-resistant Lolium rigidum (annual ryegrass) now dominates across the western australian grain belt. Weed Res. 2014;54(3):314-24. Available from: https:// doi.org/10.1111/wre.12068

Owen MJ, Martinez NJ, Powles SB. Multiple herbicide-resistant wild radish (Raphonus raphanistrum) populations dominate western australian cropping fields. Crop Past Sci. 2015;66(10):1079-85. Available from: https://doi.org/10.1071/CP15063

Owen MJ, Powles SB. Distribution and frequency of herbicide-resistant wild oat (Aveno spp.) across the Western Australian grain belt. Crop Past Sci. 2009;60(1):25-31. Available from: https://doi.org/10.1071/CP08178

Peden R. Farming in the economy: early farming and the great pastoral era. Te Ara: the Encyclopedia of New Zealand. Nov 24, 2008[access May 20, 2021]. Available from: https://teara.govt.nz/en/farming-in-the-economy/page-1

Peterson GE. The discovery and development of 2,4-D. Agric Hist. 1967;41(3):243-54

Popay I. Weeds of agriculture: weed control. Te Ara: the Encyclopedia of New Zealand. Nov 24, 2008 [access May 20, 2021]. Available from: http://www.TeAra.govt.nz/en/weeds-of-agriculture/page-5

Pratley J, Urwin N, Stanton R, Baines $\mathrm{P}$, Broster J, Cullis $\mathrm{K}$ et al. Resistance to glyphosate in Lolium rigidum I: bioevaluation. Weed Sci. 1999;47(4):405-11. Available from: https://doi.org/10.1017/ S0043174500091992 
Rahman A, editor. Current status of herbicide resistance in New Zealand weeds. Proceedings of the 9th Australian Weeds Conference; Adelaide, Australia. Adelaide: Council of Australian Weed Science Societies; 1990.

Rahman A, James T, Mortimer J, editors. Control of atrazine-resistant fat hen in maize. Proc N Z Weed Pest Control Conf. 1983;43:1-4. Available from: https://doi.org/10.30843/nzpp.1983.36.9582

Rahman A, James TK, Trolove MR, Dowsett C. Factors affecting the persistence of some residual herbicides in maize silage fields. N Z Plant Protect. 2011;64:125-32. Available from: https://doi.org/10.30843/ nzpp.2011.64.6011

Raja R, Nguyen TT, Slaughter DC, Fennimore SA. Real-time weedcrop classification and localisation technique for robotic weed control in lettuce. Biosys Eng. 2020;192:257-74. Available from: https://doi. org/10.1016/j.biosystemseng.2020.02.002

Shaner DL, Beckie HJ. The future for weed control and technology. Pest Manage Sci. 2014;70(9):1329-39. Available from: https://doi. org/10.1002/ps.3706

Somerville GJ, Powles SB, Walsh MJ, Renton M. Why was resistance to shorter-acting pre-emergence herbicides slower to evolve? Pest Manage Sci. 2017;73(5):844-51. Available from: https://doi.org/10.1002/ps.4509

State Library of New South Wales - SInsw. Australian agricultural and rural life Sydney (NSW). Sydney: State Library of New South Wales; 2021[access May 20, 2021]. Available from: https://www.sl.nsw.gov. au/stories/australian-agricultural-and-rural-life/crops-horticulture-and-viticulture

Stokstad E. The war against weeds down under. Science. 2013;341(6147):734-6. Available from: https://doi.org/10.1126/science.341.6147.734

Swanton CJ, Mahoney KJ, Chandler K, Gulden RH. Integrated weed management: knowledge-based weed management systems. Weed Sci. 2008;56(1):168-72. Available from: https://doi.org/10.1614/WS07-126.1
Temple W. Review of the evidence relating to glyphosate and carcinogenicity. Wellington: Environmental Protection Authority; 2016 [access May 16, 2021]. Available from: https://epa.govt.nz/assets/Uploads/Documents/Everyday-Environment/Publications/EPA-glyphosate-review.pdf

Troyer JR. In the beginning: the multiple discovery of the first hormone herbicides. Weed Sci. 2001;49(2):290-7. Available from: https://doi.org /10.1614/0043-1745(2001)049[0290:ITBTMD]2.0.C0;2

Walker S, Bell K, Robinson G, Widderick M. Flaxleaf fleabane (Conyzo bonoriensis) populations have developed glyphosate resistance in north-east australian cropping fields. Crop Protect. 2011;30(3):311-7. Available from: https://doi.org/10.1016/j.cropro.2010.11.010

Walsh MJ, Aves C, Powles SB. Harvest weed seed control systems are similarly effective on rigid ryegrass. Weed Technol. 2017a;31(2):17883. Available from: https://doi.org/10.1017/wet.2017.6

Walsh M, Ouzman J, Newman P, Powles S, Llewellyn R. High levels of adoption indicate that harvest weed seed control is now an established weed control practice in Australian cropping. Weed Technol. 2017b;31(3):341-7. Available from: https://doi.org/10.1017/wet.2017.9

Walsh MJ, Duane RD, Powles SB. High frequency of chlorsulfuron-resistant wild radish (rophonus rophonistrum) populations across the western australian wheatbelt. Weed Technol. 2001;15(2):199-203. Available from: https://doi.org/10.1614/0890-037X(2001)015[0199:HFOCRW]2.0.CO;2

Wardle DA, Nicholson KS, Ahmed M, Rahman A. Influence of pasture forage species on seedling emergence, growth and development of carduus nutans. J Appl Ecol. 1995;32(1):225-33. Available from: https://doi.org/10.2307/2404431

Watson J. The significance of Mr. Richard Buckley's exploding trousers: Reflections on an aspect of technological change in New Zealand dairy farming between the world wars. Agric Hist. 2004;78(3):346-60.

Zhang L, Rana I, Shaffer RM, Taioli E, Sheppard L. Exposure to glyphosate-based herbicides and risk for non-Hodgkin lymphoma: a meta-analysis and supporting evidence. Mutat Res Rev Mutat Res. 2019;781:186206. Available from: https://doi.org/10.1016/j.mrrev.2019.02.001 